\title{
Potential and management strategy of floral biodiversity in the coastal areas in East Kalimantan, Indonesia
}

\author{
RUJEHAN", PAULUS MATIUS ${ }^{\boldsymbol{\nu}}$ \\ Faculty of Forestry, Universitas Mulawarman. Jl. Penajam, Gunung Kelua, Samarinda Ulu, Samarinda 75123, East Kalimantan, Indonesia. \\ Tel.: +62-541-749068, Fax.: +62-541-735379 "email: rujehan56@gmail.com, "`email: paulusmatius1@gmail.com
}

Manuscript received: 2 January 2018. Revision accepted: 23 May 2018.

\begin{abstract}
Rujehan, Matius P. 2018. Potential and management strategy of floral biodiversity in the coastal areas in East Kalimantan, Indonesia. Biodiversitas 19: 1130-1137. Some issues such as land clearing and mining activities often arise in the coastal areas of Bukit Soeharto Forest Park, East Kalimantan, Indonesia that serves as a water catchment area. The latest land cover in this area was dominated by bush or shrub and forest cover was reduced. This research was conducted in Tanah Merah Coast and around Samboja Reservoir in the coastal area of Bukit Soeharto Forest. The purposes of this study were to determine the potential diversity of flora in the two regions and to develop management strategies in order to maintain or even to improve the diversity of flora. The method used in this research was a survey using vegetation analysis and SWOT analysis. The results showed that the species of saplings and trees dominating the forest area of Tanah Merah Coast was Nauclea orientalis, while Cratoxylum arborescens was the most prominent species of seedlings. On the other side, the forest around Samboja Reservoir was dominated by Campnosperma auriculata for trees or adult communities, Ficus retusa for saplings and Dyera costulata for seedlings. Both species diversity $\left(\mathrm{H}^{\prime}\right)$ and evenness index (E) of these areas were categorized as medium. Management strategies needed to maintain and improve the diversity and evenness of existed flora consist of S-O strategy that aims to improve the ecological functions of the area that can provide economic benefits, S-T strategy proposes cooperation with local communities to develop alternative economic activities, W-O strategy utilize the funding opportunities from donor agencies for forest management and W-T strategy includes efforts to improve human resources through training in collaboration with donor agencies.
\end{abstract}

Keywords: Bukit Soeharto Forest Park, coastal areas, the potential of flora diversity, management strategies

\section{INTRODUCTION}

Bukit Soeharto Forest Park in East Kalimantan, Indonesia has an area of 67,766 hectares designated as a conservation area. Most of its area is a coastline which is the transitional area of land and freshwater ecosystems with marine ecosystems which have the potential of rich and diverse natural resources. Odum and Barrett (2005) state that coastal ecosystem includes beaches, river mouths (estuaries), coastal forests, seagrass, swamp area and mangrove. In Indonesia, coastal area is the center of a wide range of development activities, because this area has both renewable and nonrenewable natural resources. In addition, this area also has a very good accessibility to a wide range of economic activities from several sectors, such as transportation, ports, industries, residential areas and tourism.

Utilization and management of natural resources in the coastal ecosystem need to be carried out cautiously by implementing the principles of sustainable development. However, the increase in population and intensive development may endanger and damage the capacity of coastal ecosystem in providing all the natural resources and environmental services, whereas all aspects of local communities' livelihood depend on this ecosystem. The local communities use the coastal areas for socio-economic activities and those activities might affect the existing biodiversity, so the management of natural resources needs to be taken seriously by the government. Besides, Nyurumana (2016) states that flora biodiversity is a strategic resource, as it acts as one of the determinants of the quality of human life. However, less environmentally sustainable utilization could lead to a high rate of degradation, thus threatening global biodiversity (Butchart et al. 2010; Houdet et al. 2012), especially in tropical forests with the level of degradation between $2-11 \%$ per decade (Koopowitz et al. 1994).

Regarding the issues above, there has been a disruption of Bukit Soeharto Forest Park ecosystems, both at Samboja Reservoir and Tanah Merah Coast. Damages in Samboja Reservoir, as the area of water catchment, were indicated by the practice of land clearing for agriculture and coal mining activities surrounding the area. Even the current land cover was dominated by bushes, shrubs, weeds and the forest cover was reduced; as a result, the hydrological system in this area was disturbed (Maharani 2012).

Tanah Merah Coast is one type of coastal forest ecosystems in Bukit Soeharto Forest Park. Lately, Tanah Merah Coast has become a destination of ecotourism and is frequently visited by local tourists especially on holidays. Besides having quite beautiful scenery, Tanah Merah Coast is also a habitat for many species of coastal plants (Mukhlisi and Sidiyasa 2011). Pressures derived from technology development and increasing population growth threaten the coastal ecosystem even though conservation area contributes to various aspects, including aspects of ecology, economy and science and technology (Dominggus 1999). In accordance with the characteristics of the coastal area of Bukit Soeharto Forest Park, one of the efforts to 
preserve this conservation area can be done through ecotourism activities involving local communities. In general, ecotourism not only provides ecological benefits but also economic benefits. Ecotourism activities in Forest Park are regulated in the Government Regulation No. 36, Year of 2010 concerning the management of nature tourism.

Therefore, vegetation analysis needs to be carried out to determine the components of the ecosystem, namely the species composition and structure of vegetation so that the potential of the area to be utilized and managed on an ongoing basis is in accordance with the characteristics of the area can be discovered. Nyurumana (2016) states combination between conservation-ecological benefits, social-culture-religion, and economic-earnings of flora biodiversity are the determinants of the success of its management.

SWOT analysis (Strengths, Weaknesses, Opportunities, Threats) was carried out in order to maintain or even enhance the potential values of the area that can be utilized and managed optimally. From this analysis, it can be seen what kind of strategies that must be applied to develop the coastal areas as ecotourism. Therefore, the purposes of this study were to describe the potential diversity of flora in Bukit Soeharto Forest Park, especially in the coastal areas, and to determine the development strategy of the areas to support the conservation of biodiversity, especially the existing flora.

\section{MATERIALS AND METHODS}

\section{Study site and its status history}

The research was conducted in Tanah Merah Coast Forest and Samboja Reservoir Forest of the coastal areas of Tahura Bukit Soeharto (Bukit Soeharto Forest Park), Block of Samboja, East Kalimantan Province, Indonesia. The study lasted for 5 (five) months, from January 2016 until May 2016.

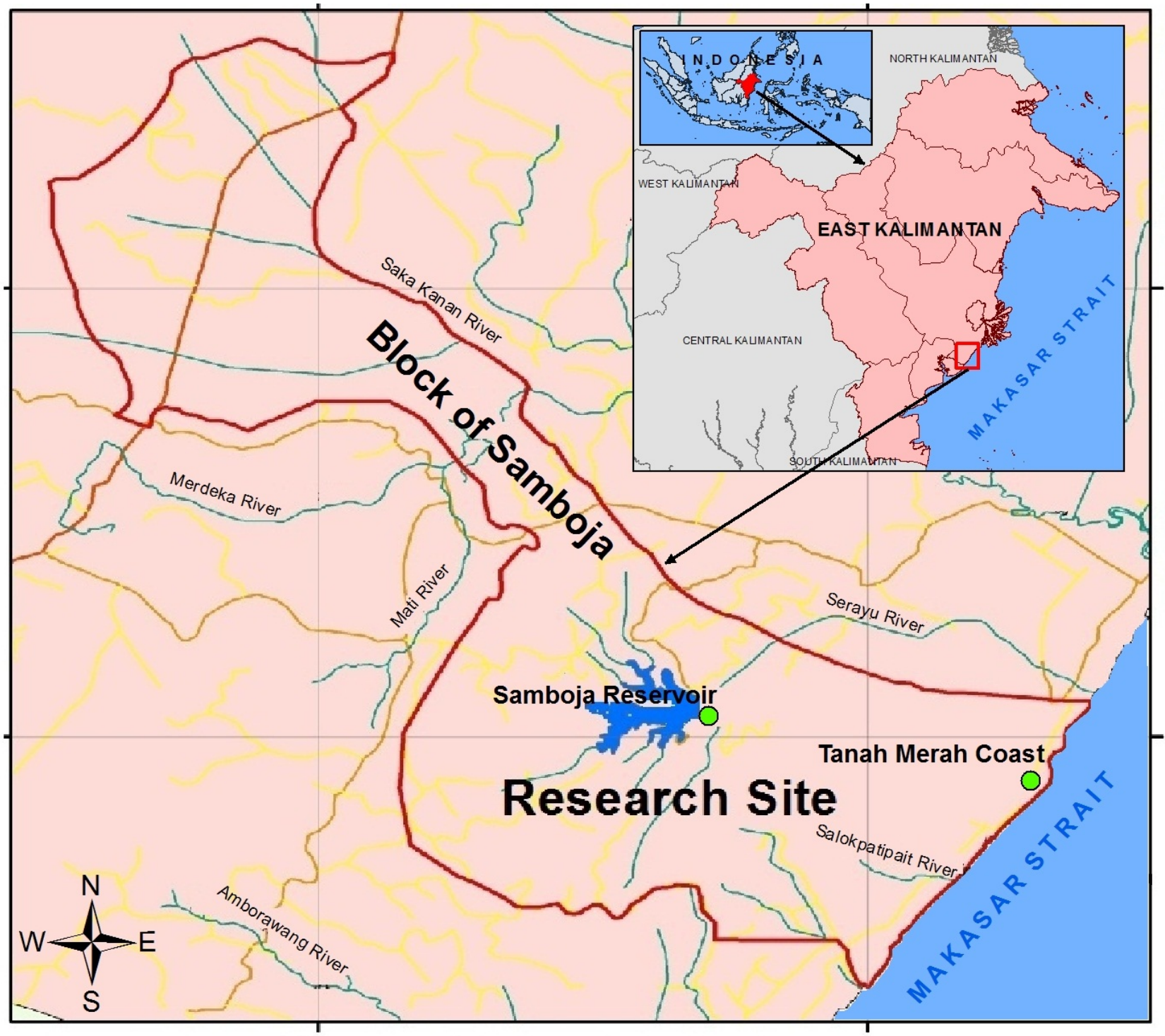

Figure 1. Map of research site in Bukit Soeharto Forest Park, Block of Samboja, East Kalimantan Province, Indonesia 
The history of Bukit Soeharto Forest Park began with the proposal of the Governor of East Kalimantan in 1976 to make this area as an environmental preservation zone (Ruyadi 2009). In its development, the forest has experienced several changes of status and function. Lastly, the Decree of the Minister of Forestry no SK.577 / MenhutII / 2009 established the area of Bukit Soeharto Forest Park covers an area of 67,766 hectares. Most of its areas are located in the coastal zone of which there is Samboja Block covering 8,212 hectares. $\square$

Data collection was carried out by a direct survey method that included primary data and secondary data. Primary data were collected through direct observation of the existing vegetation and interviews with local communities, community leaders and the forest management agency, while secondary data were gathered through the study of literature and documentation. The collected data were processed and analyzed through vegetation analysis and SWOT analysis. Vegetation analysis began by identifying the species, and calculating the number of individuals and frequency of each species and all species found in research area. Furthermore, to determine the diversity of species in the forest area, then the measurement of species diversity index $\left(\mathrm{H}^{\prime}\right)$ as proposed by Shannon-Wiener (Krebs 1985; Magurran 1988; Ludwig and Reynolds 1998; Wijana 2014) was conducted. The diversity index (H') is formulated as below.

$$
H^{\prime}=-\sum_{i=1}^{S}(P i \times \ln (P i))
$$

Where, $\mathrm{H}^{\prime}$ is the species diversity index and $\mathrm{P}_{\mathrm{i}}$ equals to $\mathrm{n}_{\mathrm{i}} / \mathrm{N}$ in which $\mathrm{n}_{\mathrm{i}}$ is the number of individuals of species $i$ th and $\mathrm{N}$ is the total number of individuals of all species in the dataset. By referring to the Shannon-Wiener Index criteria, a species diversity index can be said to be high when $\mathrm{H}^{\prime}>$ 3 , medium when $1 \leq \mathrm{H}^{\prime} \leq 3$ and low when $\mathrm{H}^{\prime}<1$ (Odum and Barrett 2005).

To determine whether the number of individuals among species was evenly distributed at a certain level of growth, an evenness index (E) was used. To get the value of $E$, Pielou (1966) in Odum and Barrett (2005) applied the following formula:

$$
E=\frac{H^{\prime}}{\ln (S)}
$$

Where, $\mathrm{H}^{\prime}$ is the species diversity index and $\mathrm{S}$ is the total number of species. Higher evenness index from a certain level of growth shows that the number of individuals among species is more evenly distributed. Evenness index ranges from 0 to 1 . Hill (1973) in Nurdahlanti (2008) classified evenness index (E) into five classes, namely: 1) distributed unevenly when the value of $\mathrm{E}$ is 0.00 to $0.25,2$ ) less evenly when $\mathrm{E}$ is 0.26 to $0.50,3$ ) fairly evenly when $\mathrm{E}$ is 0.51 to $0.75,4$ ) almost evenly when $\mathrm{E}$ is 0.76 to 0.95 , and 5 ) evenly when $\mathrm{E}$ is 0.96 to 1.00 .

SWOT analysis provides numerous formulation of strategies to maintain or even increase the values of flora diversity and ecology in the coastal area of Bukit Soeharto Forest Park. There are three processes in making a SWOT analysis so that the decision obtained can be more precise. The first process is data collection that includes evaluation of internal and external factors. The second process is developing the matrix of evaluation of internal and external factors as well as the SWOT matrix. The last process is decision-making. At this stage, a variety of alternative strategies that can be used to make decision appears. According to Hidayat et al. (2012), S-O strategy has a tendency to be aggressive, meaning that it optimizes the potential and opportunities, while the S-T strategy enables self-improvement and is made to overcome weaknesses. W-O strategy includes diversification, in which it uses strengths to minimize threats, while W-T strategy allows defensive actions, namely reducing weaknesses and avoiding threats.

\section{RESULTS AND DISCUSSION}

\section{The potential flora in the region}

The forest in Tanah Merah Coast and around Samboja Reservoir is included in the type of moderate heath forest. Hatta (2007) states that moderate heath forest is a group of forest in which its soil texture has a balanced proportion of sand and clay or with more clay proportion than sand. According to Ashton (1958) in Riswan (1987), moderate heath forest has a general characteristic of short trees with a small circumference of the trunk and a few species. There are few lianas and a lot of epiphytes with leaves that are hard and stiff as leather (schlerophyllous) on the forest floor and it shows similarities with peat swamp forests.

The soil has a low content of bases and is highly acidic, usually coarse textured and free drainage, in which the soil is often covered in a layer of peat or humus material that quickly disappear once the natural vegetation is cleared (Goeltenboth et al. 2012).

\section{Species composition}

From the results of observation, the floristic composition of vegetation at seedling stage in Tanah Merah Coast and around Samboja Reservoir is presented in Table 1. Table 1 shows that the total number of species of seedlings at Tanah Merah Coast area was higher (9 species) than that of Samboja Reservoir. This indicates that the species present at Tanah Merah Coast were better in competing with other species. Facts on the field showed that the habitats of Tanah Merah Coast were drier and more open than in Samboja Reservoir region where the habitats were closed and most of them were waterlogged. In a closed habitat, it is generally difficult for vegetation particularly seedlings to grow evenly and they tend to prefer certain locations that are not flooded. Fatem and Sykora (2012) mention plants common in open to closed forest have a wide amplitude concerning light conditions and can grow both in open forests and below the canopy of tall trees. Some have their optimum growth in shade while other species grow better in the presence of light. For 
instance, according to Siappa, et al. (2016), a species in a certain family such as Moraceae which grows in Tanah Merah Coast area more tolerant to a habitat that has dry soil, abundance of sunshine, dry or health area, but it also requires habitat conditions near streams and springs. Some areas around the river are sandy and composed of limestones so that it tends to have minimum amount of nutrient for plants. $\square$

The floristic composition of the vegetation at sapling stage in Tanah Merah Coast and around Samboja Reservoir area is presented in Table 2.

Table 2 shows that the forest around Samboja Reservoir had more number of species of saplings with 17 species than that in Tanah Merah Coast where there were only eight species. The difference in habitat conditions as mentioned earlier could be the cause of it, even though both are included in the moderate heath forest area. Species richness of the heath forest in undisturbed Samboja sand mountain on saplings consists of 28 species of 22 genera in 17 families (Riswan 1987).

The number of species of seedlings and saplings in Tanah Merah Coast area did not differ significantly (see Table 1 and Table 2), while at the Samboja Reservoir area significantly differed. The research conducted by Fontes et al. (2015) reveals that once plants start to grow and become sapling, the floristic composition of forest changes remarkably. This shift in floristic composition suggests that soil waterlog may act as a strong abiotic filter in the assembly of juvenile and adult communities.

The floristic composition of the vegetation at tree stage in Tanah Merah Coast and around Samboja Reservoir is presented in Table 3. Table 3 shows that the number of trees species growing in the forest near Samboja Reservoir was higher than that in Tanah Merah Coast (see Table 3). A research conducted by Riswan (1987) on undisturbed Samboja sand mountain vegetation discovered 24 species of 18 genera in 13 families at tree stage.

The presence of pioneer species such as Cratoxylum cochinchinense, Vitex pinnata, Vitex trifolia, Macaranga spp., Dillenia suffruticosa, and Euodia alba, indicates that the forest both in Tanah Merah Coast and around Samboja Reservoir can be categorized as an old secondary forest that will continue its succession over time and reach the climax forest stage, assuming no physical disturbances such as forest fires or land clearing for plantations occur.

Overall there was an increase in the number of species from the seedling, sapling and tree stages. This condition indicates that the ecosystem in these areas can still be maintained or enhanced.

According to Dendang and Handayani (2015), vegetation composition is normal or balanced, if the number of individuals of seedlings is more than saplings, the number of saplings is more than poles, and the number of poles is more than the trees, so that the regeneration process can take place since there are sufficient amount of plants at early stages. However, the composition of the vegetation in the forest area of Tanah Merah Coast and Samboja Reservoir was slightly unbalanced. Clay-soil texture on both regions might be the cause.

\section{Species diversity and evenness index}

A community may consist of various species or several species. It is necessary to calculate species diversity $\left(\mathrm{H}^{\prime}\right)$ for each stage of vegetation. Figure 2 presents the values of species diversity index for each stage of vegetation at Tanah Merah Coast and around Samboja Reservoir.

Table 1. The vegetation composition at seedling stage at Tanah Merah Coast and around Samboja Reservoir, Bukit Soeharto Forest Park, Block of Samboja, East Kalimantan Province, Indonesia

\begin{tabular}{lccl}
\hline & \multicolumn{2}{c}{ Region } & \\
\cline { 2 - 3 } Species & $\begin{array}{c}\text { Tanah } \\
\text { Merah } \\
\text { Coast }\end{array}$ & $\begin{array}{c}\text { Samboja } \\
\text { Reservoir }\end{array}$ & Family \\
\hline $\begin{array}{l}\text { Cratoxylum arborescens } \\
\text { Cratoxylum maingayi }\end{array}$ & $\sqrt{ }$ & - & Hyperaceae \\
Clydemia hirta & - & - & Hyperaceae \\
Dyera costulata & - & $\sqrt{ }$ & Melastomataceae \\
Ficus nervosa & $\sqrt{ }$ & - & Apocynaceae \\
Meiogyne virgata & $\sqrt{ }$ & - & Annonaceae \\
Mallotus paniculatus & - & $\sqrt{ }$ & Euphorbiaceae \\
Nauclea orientalis & $\sqrt{ }$ & - & Rubiaceae \\
Shorea balangeran & $\sqrt{ }$ & - & Dipterocarpaceae \\
Shorea sp. & $\sqrt{ }$ & - & Dipterocarpaceae \\
Syzygium sp. & - & $\sqrt{ }$ & Myrtaceae \\
Tristania beccarii & $\sqrt{ }$ & - & Myrtaceae \\
Vitex pinnata & $\sqrt{ }$ & $\sqrt{ }$ & Lamiaceae \\
Total & 9 & 5 & 10 \\
\hline
\end{tabular}

Table 2. The vegetation composition at sapling stage in Tanah Merah Coast and around Samboja Reservoir, Bukit Soeharto Forest Park, Block of Samboja, East Kalimantan Province, Indonesia

\begin{tabular}{lccll}
\hline & \multicolumn{3}{c}{ Region } & \\
\cline { 2 - 3 } Species & $\begin{array}{c}\text { Tanah } \\
\text { Merah } \\
\text { Coast }\end{array}$ & $\begin{array}{c}\text { Samboja } \\
\text { Reservoir }\end{array}$ \\
\hline Campnosperma auriculata & - & $\sqrt{ }$ & Anacardiaceae \\
Meiogyne virgata & - & $\sqrt{ }$ & Annonaceae \\
Vernonia arborea & - & $\sqrt{ }$ & Asteraceae \\
Calophyllum inophyllum & - & $\sqrt{ }$ & Clusiaceae \\
Garcinia diversifolia & - & $\sqrt{ }$ & Clusiaceae \\
Dillenia suffruticosa & - & $\sqrt{ }$ & Dilleniaceae \\
Shorea balangeran & $\sqrt{ }$ & - & Dipterocarpaceae \\
Shorea sp. & $\sqrt{ }$ & - & Dipterocarpaceae \\
Macaranga triloba & $\sqrt{ }$ & $\sqrt{ }$ & Euphorbiaceae \\
Caranga arborescens & - & $\sqrt{ }$ & Leguminosae \\
Cratoxylum arborescens & $\sqrt{ }$ & $\sqrt{ }$ & Hypericaceae \\
Vitex pinnata & - & $\sqrt{ }$ & Lamiaceae \\
Vitex trifolia & - & $\sqrt{ }$ & Lamiaceae \\
Ficus retusa & - & $\sqrt{ }$ & Moraceae \\
Syzygium lineatum & - & $\sqrt{ }$ & Myrtaceae \\
Syzygium pseudoformosum & $\sqrt{ }$ & $\sqrt{ }$ & Myrtaceae \\
Syzygium sp. & - & $\sqrt{ }$ & Myrtaceae \\
Tristaniopsis obovata & - & $\sqrt{ }$ & Myrtaceae \\
Tristania beccarii & $\sqrt{ }$ & - & Myrtaceae \\
Nauclea orientalis & $\sqrt{ }$ & $\sqrt{ }$ & Rubiaceae \\
Nephelium mutabile & $\sqrt{ }$ & - & Sapindaceae \\
Total & 8 & 17 & \\
\hline & & & \\
\hline & & &
\end{tabular}


Table 3. The vegetation composition at tree stage in Tanah Merah Coast and around Samboja Reservoir, Bukit Soeharto Forest Park, East Kalimantan Province, Indonesia

\begin{tabular}{|c|c|c|c|}
\hline \multirow[b]{2}{*}{ Species } & \multicolumn{2}{|c|}{ Region } & \multirow[b]{2}{*}{ Family } \\
\hline & $\begin{array}{c}\text { Tanah } \\
\text { Merah } \\
\text { Coast }\end{array}$ & $\begin{array}{l}\text { Samboja } \\
\text { Reservoir }\end{array}$ & \\
\hline Alstonia campanulata & - & $\sqrt{ }$ & Euphorbiaceae \\
\hline Calophyllum inophyllum & $\sqrt{ }$ & $\sqrt{ }$ & Clusiaceae \\
\hline Casuarina equisetifolia & $\sqrt{ }$ & - & Casuarinaceae \\
\hline Cratoxylum arborescens & $\sqrt{ }$ & $\sqrt{ }$ & Hyperaceae \\
\hline Cratoxylum cochinchinense & $\sqrt{ }$ & - & Hyperaceae \\
\hline Cratoxylum maingayi & $\sqrt{ }$ & - & Hyperaceae \\
\hline Ficus nervosa & $\sqrt{ }$ & $\sqrt{ }$ & Moraceae \\
\hline Ficus retusa & $\sqrt{ }$ & $\sqrt{ }$ & Moraceae \\
\hline Meiogyne virgata & $\sqrt{ }$ & $\sqrt{ }$ & Annonaceae \\
\hline Nauclea orientalis & $\sqrt{ }$ & $\sqrt{ }$ & Rubiaceae \\
\hline Nuclea sp. & $\sqrt{ }$ & - & Rubiaceae \\
\hline Palaquium rostratum & $\sqrt{ }$ & - & Sapotaceae \\
\hline Shorea balangeran & $\sqrt{ }$ & - & Dipterocarpaceae \\
\hline Symplocos racemosa & $\sqrt{ }$ & $\sqrt{ }$ & Symploceae \\
\hline Syzygium lineatum & $\sqrt{ }$ & - & Myrtaceae \\
\hline Syzygium pseudoformosum & $\sqrt{ }$ & $\sqrt{ }$ & Myrtaceae \\
\hline Syzygium sp. & $\sqrt{ }$ & - & Myrtaceae \\
\hline Terminalia catappa & $\sqrt{ }$ & - & Combretaceae \\
\hline Tristania beccarii & $\sqrt{ }$ & - & Myrtaceae \\
\hline Tristaniopsis obovata & $\sqrt{ }$ & $\sqrt{ }$ & Myrtaceae \\
\hline Vitex pinnata & $\sqrt{ }$ & $\sqrt{ }$ & Lamiaceae \\
\hline Dillenia suffruticosa & - & $\sqrt{ }$ & Dilleniaceae \\
\hline Eugenia sp. & - & $\sqrt{ }$ & Myrtaceae \\
\hline Euodia alba & - & $\sqrt{ }$ & Rutaceae \\
\hline Campnosperma auriculata & - & $\sqrt{ }$ & Anacardiaceae \\
\hline Caranga arborescens & - & $\sqrt{ }$ & Leguminosae \\
\hline Garcinia diversifolia & - & $\sqrt{ }$ & Clusiaceae \\
\hline Litsea sp. & - & $\sqrt{ }$ & Lauraceae \\
\hline Macaranga gigantea & - & $\sqrt{ }$ & Euphorbiaceae \\
\hline Macaranga hosei & - & $\sqrt{ }$ & Euphorbiaceae \\
\hline Macaranga pruinosa & - & $\sqrt{ }$ & Euphorbiaceae \\
\hline Macaranga triloba & - & $\sqrt{ }$ & Euphorbiaceae \\
\hline Maducha sp. & - & $\sqrt{ }$ & Sapotaceae \\
\hline Shorea aibida & - & $\sqrt{ }$ & Dipterocarpaceae \\
\hline Syzygiumzeylanicum & - & $\sqrt{ }$ & Myrtaceae \\
\hline Vernonia arborea & - & $\sqrt{ }$ & Asteraceae \\
\hline Vitex trifolia & - & $\sqrt{ }$ & Lamiaceae \\
\hline Total & 20 & 27 & \\
\hline
\end{tabular}

Figure 2 shows that the $\mathrm{H}^{\prime}$ value of vegetation at seedling stage in Tanah Merah Coast area was 1.87, higher than that around Samboja Reservoir, which was only 1.48. In the forest area of Tanah Merah Coast, there is a gap between the tree canopy that allows light to enter to the forest floor, so new species can grow. While near Samboja Reservoir, the area is more closed and has limited light entering the forest floor.

According to Odum and Barrett (2005) the value of $\mathrm{H}^{\prime}$ can be used to determine the effects of disturbance on the environment or to find out stages of succession and stability of plant communities at a site. The values of $\mathrm{H}^{\prime}$ of vegetation both in Tanah Merah Coast and around Samboja
Reservoir at seedling stage, that ranged from 1-3 (Figure 2 ), were classified as medium. This indicates that the level of species diversity of seedlings in both regions could still be maintained or improved.

At the sapling and tree stages, the forest around Samboja Reservoir had higher H' than that in Tanah Merah Coast area. The values of $\mathrm{H}^{\prime}$ of vegetation at sapling and tree stages which ranged from 1 to 3 were classified as medium, the same as the seedlings.

According to Odum and Barrett (2005), diversity tends to increase in older communities and is low in the newlyformed communities. The $\mathrm{H}^{\prime}$ value of vegetation at the sapling and tree stages showed that the community in the two areas can maintain species diversity against environmental disturbance or climate change.

According to Sodhi (2004) in Gunawan et al. (2005), the level of species diversity in an area is influenced by several factors, two of which are the diversity or quality of habitat and disturbance from human activities. Based on the facts on the field, there are quite a lot of human activities in forest areas in Tanah Merah Coast and around Samboja Reservoir since both of these areas are easy to reach. Some local communities were seen going in and out of the areas for a variety of purposes, such as recreation, gardening or farming, and feeding cattle. $\square$

Furthermore, to determine whether the number individuals among species are distributed evenly for a certain stage of growth, it is necessary to calculate the value of species evenness index (E). The value of species evenness index for each stage of vegetation at Tanah Merah Coast and Samboja Reservoir is presented in Figure 3.

Based on the $\mathrm{E}$ values that ranged from 0.85 to 0.92 (Figure 3), the number of individuals among species for all stages of vegetation (seedlings, saplings, and trees) can generally be categorized as fairly evenly distributed. This refers to the evenness index standards set by Hill (1973) in Nurdahlanti (2008) which ranged from 0.76 to 0.95 for fairly evenly. Kuswandi et al. (2015) mention that the high evenness index is proportional to species diversity index, meaning that the higher the evenness index value is, the higher the species diversity index value will be. $\square$

\section{Regional management strategy}

As described earlier, the analysis used to obtain the formulation of regional management strategy was the SWOT analysis. According to Boseman and Phatak (1989), SWOT analysis enables an organization to formulate and implement strategies aimed at accomplishing its organizational mission and objectives. Information collected and analyzed in the SWOT analysis may suggest that changes be made in either the mission, objectives, policies, or strategies of the organization. This analysis begins by identifying and evaluating various internal factors (strengths and weaknesses) and external factors (opportunities and threats). The results of internal and external factors evaluation, as well as alternative strategies for coastal area management in Bukit Soeharto Forest Park, are presented in Table 4 . 


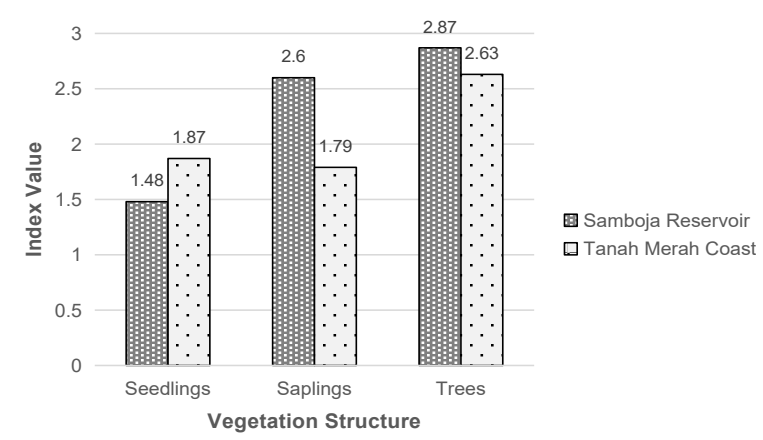

Figure 2. Species diversity index $\left(\mathrm{H}^{\prime}\right)$ of forest around Samboja Reservoir and in Tanah Merah Coast, Bukit Soeharto Forest Park, East Kalimantan Province, Indonesia

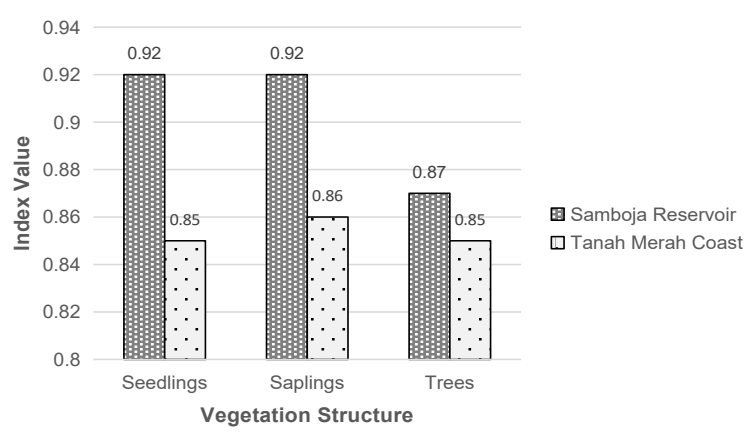

Figure 3. Species evenness index (E) of the forest around Samboja Reservoir and in Tanah Merah Coast, Bukit Soeharto Forest Park, East Kalimantan Province, Indonesia

Table 4. The matrix of SWOT analysis and alternative management strategies of flora diversity in coastal area of Bukit Soeharto Forest Park, East Kalimantan Province, Indonesia

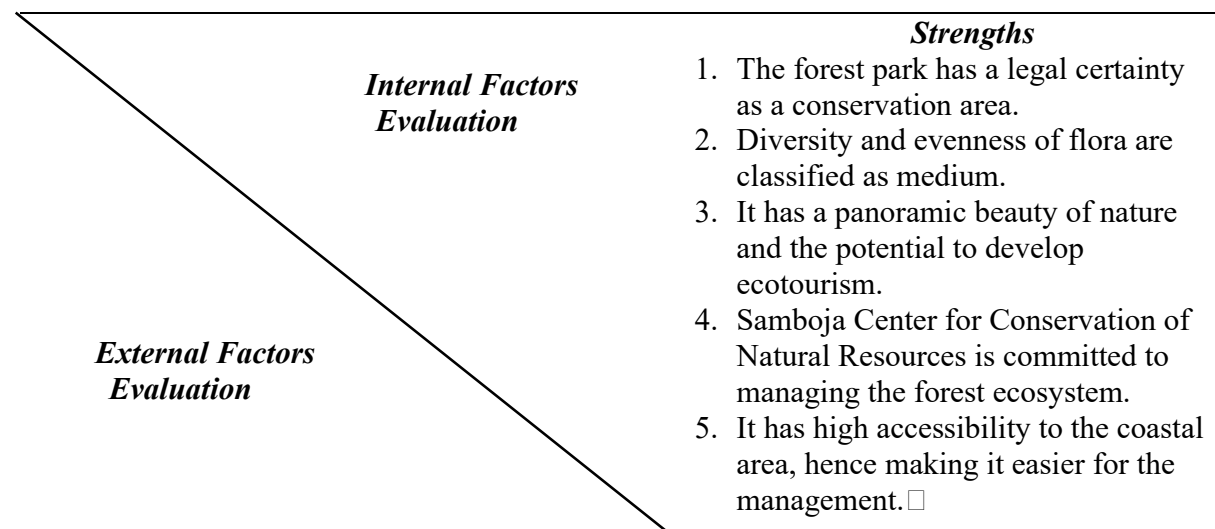

1. East Kalimantan Provincial Government and KutaiKartanegara District have been committed to developing "Kaltim Green" program.

2. There is a Regional Autonomy Policy associated with the management area.

3. There are supports of parties (local governments, universities, research agencies, NGOs, and communities) through collaborative management in the protection of flora and ecosystems diversity.

4. There is improvement of forest resource conservation policy on the management of protected areas.

5. There is a good public perception toward the preservation of the forest area as a tourist destination that supports local economies.

\section{SO Strategy}

1. Optimizing the regional management that can provide ecological and economic benefits.

2. Developing management information systems with the use of information technology in improving the ecological values of the area.

3. Developing ecotourism for the region by involving local communities.

\section{Weaknesses}

1. The forest park has limited human resources and financial capability in supporting the management.

2. There is no block clarity in the management of coastal areas.

3. It has low infrastructure quality.

4. It lacks management program of socialization on a regular basis regarding the status and function of the coastal areas.

5. It lacks directional resource conservation programs (protection, preservation, and utilization). $\square$

\section{WO Strategy}

1. Building partnerships with donor agencies to support regional management.

2. Building a participatory regional boundary.

3. Creating participatory planning with the aim of maintaining and improving the function of region. $\square$

\section{Threats}

1. There is an increasing need for land for development.

2. Local communities are highly dependent on natural resources.

3. The forest area is prone to encroachment by local communities considering that the location is close to the residential area.

4. Population growth contributes to the increasing demand for land. $\square$

5. The political support consistency that could at any time.

\section{ST Strategy}

1. Reducing local communities' reliance on natural resources by seeking alternative economic activities and employment.

2. Optimizing the use of existing facilities and infrastructure to conduct surveillance of the area.

3. Creating programs for environmental education and conservation to local communities, so as to grow the sense of belonging.

\section{WT Strategy}

1. Cooperating with relevant agencies in order to increase the capacity of Human Resource Management.

2. Preserving flora and ecosystems by involving stakeholders that are attentive to conservation.

3. Building cooperation with universities regarding social potency data collection, including potential business to be developed for economic improvement. 
Table 4 provides a variety of SO, ST, WO and WT strategies. The SO strategy suggests that the management of these areas will not only attempt to maintain the existence of the area, but also to increase the function of region that can provide ecological and economic benefits. Forest utilization often works based on direct benefits in the form of tangible resources, such as bamboo, wood, oil, latex and so on, although intangible benefits in the form of immaterial or use of services such as ecotourism can be used as an alternative to support long-term development of the country (Purnamasari et al. 2005). The development of ecological benefits is meant to increase the species diversity and evenness, while the development of economic benefits shows the involvement of local communities to develop ecotourism activities. According to Suryawan et al. (2015), ecotourism can be developed in the form of conservation tour package that allows visitors to understand the meaning and be directly involved in conservation activities. Therefore socialization through promotion becomes important in this case as it aims to optimize the utilization of the region.

Meanwhile, ST strategy implies that the management should cooperate with the local communities to consider alternative business and jobs. Kustanti et al. (2012) state that the economic development should be carried out by the utilization of the potential products whereas the institutional development of the community can be done by means of activating again rural economic institutions such as village cooperatives. This effort will support the preservation of the region and the welfare of local communities as mandated by Government Regulation No. 36, Year of 2010. However, intensive forest utilization by local communities that can disrupt ecological values needs to be held to prevent further damages. Therefore it is necessary for the management to educate local communities through a program of environmental education and conservation, thereby creating awareness and the sense of belonging. This will encourage public intention to conduct environmentally sustainable economic activities.

WO strategy aims at utilizing funding opportunities from donor agencies in order to maximize the regional management. This strategy should be implemented within the framework of integrated participatory forest planning with clear regional boundaries, thus ensuring the enhancement of forest function in both ecological and economic aspects. According to Paramastuti and Chofyan (2013) in order to achieve optimum result of the forest function enhancement, then this integrated plan needs to be further elaborated, with the spatial concept of zoning essentially serves as a management tool for activities in a forest park. For example, Gunung Kunci Forest Park has three zones: protection zone, rehabilitation and preservation zone and utilization zone and Ir. H. Juanda Forest Park has four zones: protection zone, flora and fauna preservation zone, limited utilization zone and intensive utilization zone. Furthermore, the achievement of these two aspects is in accordance with the mandate of the Indonesian Act of 1945, article 33, paragraph 3 concerning principle of natural resources for the welfare of the community.
WT strategy focuses on efforts to work with various parties to overcome the limitations of fund management. Forest management agency can take the advantages of donor agencies to finance various activities, especially those related to the problem of low human resources. In order to improve the human resources, there should be a provision of management and technical training related to conservation. Management training is aimed at collaborating management, while technical training is directed to the preservation of flora and the ecosystem. Referring to the research by Suharjito (2011), forest park collaborative management can be developed through a process of participatory action research. This participatory research includes group discussions focused on the participation of the local communities in identifying the problems encountered, collaboration between the Forestry Agency and local communities, improving local communities' capacity, and restoring the area of forest park through forest restoration, rehabilitation, and agroforestry. Also, the forest management agency can involve stakeholders including the local communities in preserving flora and the ecosystem. Public participation in conserving biodiversity of flora are important components that need to be considered and developed, especially to reduce the rate of environmental and natural resources degradation (Suryawan et al. 2015). Edward and Abivardi (1998) state that anyone who becomes involved in conservation work soon discovers that it is a truly multidisciplinary activity. On the other hand, to cope with external threats from the local communities, the forest management agency needs to collect data on socioeconomic by involving universities. The data obtained can be used as the basis for management policy.

\section{Conclusions}

A drier and more open forest in Tanah Merah Coast compared to a mostly waterlogged around Samboja Reservoir area enabled vegetation at seedling stage to grow better. Meanwhile, the number of species at sapling stage in the forest around Samboja Reservoir was higher than that in Tanah Merah Coast. The same condition was found for the tree stage of vegetation in these areas. Species diversity $\left(\mathrm{H}^{\prime}\right)$ of seedlings at Tanah Merah Coast forest area was higher than that around Samboja Reservoir. However, the later had a higher diversity of saplings and trees. In terms of species evenness (E), the number of individuals among species for each vegetation stage in the two areas were distributed fairly evenly.

SO strategy proposes attempts to increase the ecological functions that can provide economic benefits, while ST strategy suggests the management agency to cooperate with local community to consider alternative business and jobs. WO strategy aims at utilizing funds from donor agencies which can be done through the application of integrated participatory forest planning that ensures improvement in both ecological and economic aspects, while WT strategy utilizes the funds to improve the quality of human resources that can be achieved through the provision of a collaborative management training and a 
technical training that aims at preserving the flora and the ecosystems.

\section{ACKNOWLEDGEMENTS}

The authors gratefully acknowledge the support of the Management Agency of Bukit Soeharto Forest Park for its admission in conducting this research project. We would like to thank Mulawarman University for the financial support to complete this research. Gratitude and acknowledgments are addressed to the respondents who were interviewed during the field data collection. We also appreciate the comments and critiques from anonymous reviewers for this manuscript. $\square$

\section{REFERENCES}

Boseman G, Phatak A. 1989. Strategic Management. Second Edition.John Wiley and Sons, New York.

Butchart SHM, Walpole M, Collen B, Strien AV, Scharlemann JPW. 2010. Global Biodiversity: Indicators of Recent Declines. Science 328: 1164-1168.

Dendang B, Handayani W. 2015. Structure and composition of forest stand in Mount Gede Pangrango National Park, West Java; Proceeding of the Indonesia Biodiversity Society National Seminar. Yogyakarta, 21 Maret 2015. [Indonesian]

Dominggus. 1999. Material for Management of Natural Resources in Bunaken National Park Area; The Workshop of Natural Resource Management Program. Novotel Hotel, Manado, 24-27 Agustus 1999. [Indonesian]

Edwards PJ, Abivardi C. 1998. The Value of Biodiversity: Where Ecology and Economy Blend. Biol Conserv 83 (3): 239-246.

Fatem S, Sykora KV. 2012. Tropical forest types in West Papua, the presence of forest wallaby (Dorcopsis muelleri) and human disturbance. Biotropia 19 (2): 64-79.

Fontes CG, Walter BMT, Pinto JRR, Damasco G. 2015. Species turnover across different life stages from seedlings to canopy trees in swamp forests of Central Brazil. Intl $\mathrm{J}$ Ecol. 124851, 8 pages. DOI: $10.1155 / 2015 / 124851$

Goeltenbvoth F, Timotius KH, Milan PP, Margraf J. 2012. South-Eas Asia Ecology, Indonesian Archipelago. Salemba Teknika, Jakarta.

Gunawan H, Putri IASLP, Qiptiyah M. 2005. Diversity of bird species in Malili Research Area, East Luwu District, South Sulawesi. Jurnal Penelitian Hutan dan Konservasi Alam 2 (3): 241-250. [Indonesian]

Hatta GM. 2007. Distribution of tropical pitcher plant in heath forest based on environmental aspects of vegetation and soil. Rimba Kalimantan 12 (2): 102-105. [Indonesian]

Hidayat, Wibowo NM, Riswati F, Humaidi F. 2012. Increasing labor competitiveness of agro-industry sector in Indonesia through Certification. Jurnal Aplikasi Manajemen 10 (2): 357-370. [Indonesian]
Houdet J, Trommetter M, Weber J. 2012. Understanding changes in business strategies regarding biodiversity and ecosystem services. Ecol Econ 73: 37-46.

Koopowitz H, Thornhill AD, Andersen M. 1994. A general stochastic model for the prediction of biodiversity losses based on habitat conversion. Conserv Biol 8 (2): 425-438.

Krebs CJ. 1985. Ecology: The Experimental Analysis of Distribution and Abundance. 3rd ed. Harper and Row, New York.

Kustanti A, Nugroho B, Darusman D, Kusmana C. 2012. Integrated management of mangroves ecosystem in Lampung Mangrove Center (LMC) East Lampung Regency, Indonesia. Coast Dev 15 (2): 209216.

Kuswandi R, Sadono R, Supriyatno N, Marsono D. 2015. Diversity of stand structure in logged-over forest based on Papua biogeography. Jurnal Manusia dan Lingkungan 22 (2): 151-159. [Indonesian]

Magurran AE. 1988. Ecological Diversity and Its Measurements. Cambridge University Press, Cambridge, UK.

Maharani NA. 2012. Study on Sedimentation in Samboja Reservoir Kutai Kartanegara District. [Thesis]. Universitas Mulawarman, Samarinda. [Indonesian]

Mukhlisi, Sidiyasa K. 2011. Ecological aspects of nyamplung (Calophyllum inophyllum L.) in the forest area of Tanah Merah Coast, Bukit Soeharto National Park. Jurnal Penelitian Hutan dan Konservasi Alam 8 (4): 385-397. [Indonesian]

Njurumana GN. 2016. Village community and flora biodiversity management in home garden system at Central of Sumba District. Jurnal Penelitian Kehutanan Wallacea 5 (1): 25-36. [Indonesian]

Nurdahlanti L. 2008. Diatoms community structure in the waters of Penjaliran Island East, Kepulauan Seribu and Teluk Jakarta. [MinorThesis]. Universitas Indonesia, Depok. [Indonesian]

Odum E, Barrett GW. 2005. Fundamentals of Ecology. 5th ed. Thomson Brooks/Cole, Belmont, CA.

Paramastuti D, Chofyan I. 2013. Zoning of Gunung Kunci Forest Park in Urban Area of Sumedang District. Jurnal Perencanan Wilayah dan Kota 13 (1): 1-12. [Indonesian]

Purnamasari, Qurie, Irawan A, Muntasib EKSH. 2005. Study on the development of outdoor recreation product considering the ecology aspect in Wana Wisata Curug Cilember (WWCC), Bogor Regency. J Trop Forest Manag 11 (1): 14-30.

Riswan S. 1987. Kerangas Forest at Gunung Pasir, Samboja, East Kalimantan. Its Structural and Floristic Composition. Proceedings of the Third Round Table Conference on Dipterocarps. MAB, UNESCO, Regional Office of Science and Technology for South East Asia. Samarinda, 16-20 April 1985. [Indonesian]

Siappa, Hariany, Hikmat A, Kartono AP. 2016. Vegetation composition, distribution patterns, and habitat factors of Ficus magnoliifolia (Nunu Pisang) in Pangale Forest of Toro village, Central Sulawesi. Buletin Kebun Raya 19 (1): 33-46. [Indonesian]

Suharjito D. 2011. Building Collaborative Management of Conservation Forest in Indonesia. Proceedings of the National Seminar on Conservation of Tropical Plants: Current Condition and Future Challenges. Cibodas Botanical Garden Plant Conservation CenterLIPI, Cibodas, 7 April 2011. [ Indonesian]

Suryawan A, Christita M, Yuliantoro I. 2015. Potential and development strategies of Mount Tumpa Great Forest Park, Manado, North Sulawesi to conserve the biodiversity of Wallacea subregion. Pros Sem Nas Masy Biodiv Indon 1: 714-720. [Indonesian]

Wijana, Nyoman. 2014. Vegetation Analysis Methods. Plantaxia, Indonesia. 